\title{
An Empirical Test for Natural Rate of Unemployment and Expectations Augmented Phillips Curve Hypothesis in Perspective of Chinese Economy
}

\author{
Mazhir Nadeem Ishaq ${ }^{a}$, Sana Batool ${ }^{b}$, Rukhsana Rasheed ${ }^{\mathrm{c}}$ \\ ${ }^{a}$ Department of Economics, The Islamia University of Bahawalpur, Pakistan \\ Email: mazhir.nadeem@iub.edu.pk \\ ${ }^{\mathrm{b}}$ Department of Management Sciences, The Govt. Sadiq College Women University Bahawalpur, Pakistan \\ ${ }^{c}$ Department of Management Sciences, The Govt. Sadiq College Women University Bahawalpur, Pakistan
}

\begin{tabular}{|c|c|}
\hline LE DETAILS & ABSTRACT \\
\hline Histor & \multirow{10}{*}{$\begin{array}{l}\text { This research study investigates the natural rate of unemployment and } \\
\text { the Expectations Augmented Phillips Curve for Chinese economy by } \\
\text { analyzing the data ranging from } 1980 \text { to } 2020 \text {. The empirical } \\
\text { methodology of this study test the relationship between inflation rate } \\
\text { and rate of unemployment which proved to be negatively significant (it } \\
\text { proves the existence of classical Phillips Curve around 196o) in China. } \\
\text { The study also analyzed the Expectations Augmented Phillips Curve } \\
\text { allowing the effects of price expectations on money wages increases. } \\
\text { Finally, the study also analyzed the natural rate of unemployment for } \\
\text { China that was around } 4.86 \text { per cent that can be compared with the } \\
\text { natural rate of unemployment (as prescribed by economists } 4 \text { to } 5 \text { per } \\
\text { cent). The study suggests certain tools that will be helpful for } \\
\text { policymakers in maintaining the conditions of stable inflation in China. }\end{array}$} \\
\hline Acce & \\
\hline Available Onl & \\
\hline Keywords: & \\
\hline Natural Rate of $U$ & \\
\hline Expectations Augmented Phillips & \\
\hline Curve, China & \\
\hline JEL Classification: & \\
\hline$E O O, E 24, E 31$ & \\
\hline & \\
\hline
\end{tabular}

DOI: $10.47067 /$ reads.v7i4.412

(C) 2021 The authors. Published by SPCRD Global Publishing. This is an open access article under the Creative Commons Attribution-

NonCommercial 4.0

Corresponding author's email address: mazhir.nadeem@iub.edu.pk

\section{Introduction}

Phillips curve changes over time and is different for different economies. With time, the conventional Phillips Curve shows contradictory findings. Economists in recent years argued the "broken down" nature of the Phillips Curve (Summers, 2017). Even Phillips curve slope in recent decades has become flatter. Ashiya in 2017 finds the Japanese Phillips curve with a constant inflation rate of non-accelerating for unemployment and finds find the productivity coefficient to be positive through regression analysis and it was contradictory so they use modified Phillips curve relation.

The government and business used various forecasting models for macroeconomic policies. The expectations- augmented Philips curve is a fundamental element for almost every model. The classical theories assumed that without systematic error, prices adjusted freely while the expectations developed 
rationally. Therefore, assumptions imply that Philips curve is steep and any deviation from NAIRU is short-lived. Price and wage inertia will results to move away real wage and relative price prices from market clearing levels.

Phillips Curve changes over time and is different for different economies so what would be the Phillips Curve in the situation of Deflation. The conventional Phillips curve explains the situation of high inflation but what happens with low inflation or if inflation is negative (at deflation). When deflation starts Phillips curve relation break down due to the main worker's reluctance reasons to accept fall in wages nominally. This means that workers are accepting a real wages cut which occurs only when wages nominally increases more slowly than rate of inflation. If this argument works, unemployment and inflation relation in the Phillips curve may disappear. This situation of deflation exists in many countries due to very low inflation. One of the best examples is negative inflation in Japan since the 1990 .

The combined action of both structural and frictional unemployment is measured in natural rate of unemployment. Such a situation in a country may exist due to equilibrium in labour market and expansion in economy. Even developed economies may also experience this situation of natural rate of unemployment because many workers are trying to get better jobs. The Federal Reserve estimates the natural rate of unemployment to be at 3.5 per cent to 4.5 per cent for achieving the goals of full employment. Here, the question is why Economists don't want the unemployment rate at zero? There is only one way the economy could have an unemployment rate at zero it is the situation of overheated. Even a very developed economy the United States of America never experienced an unemployment rate at zero. Only in 1953, the lowest unemployment recorded was 2.5 per cent it was due to overheating of the United States economy during Korean War, after that when the bubble burst the recession of 1953 stars.

In 1926, Irving Fisher identified the Phillips curve statistically using bidirectional causation between unemployment and inflation. Philips curve was graphed and plotted by A.J. Brown in 1955, Jan Tinbergen in 1936, Lawrence Klein and Arthur Goldberger in 1955, Arthur W. Philips in 1958. The formulation of Expectations Augmented Phillips Curve was made in 1970. Humphrey (1985) studied the Phillips curve and makes some innovations; First: re-specification of excess demand variable, Second: he innovate the Expectations Augmented Equation. Mitra (2012) showed that for Solow and Samuelson PC a rise in 4 per cent to 5.5 per cent will result in a 3 per cent to 2.5 per cent fall in inflation.

\section{The Review of Literature}

Franz (2005), Karanassou and Sala (2010) finds a negative unemployment and inflation relationship. Niskanen (2002), Taiwoo et al. (2013) found a positive link between the rates of unemployment and inflation. Brauer (2007) concluded that a variety of factors cause the flactuation in busness cycle and hence so the natural rate of unemployment. The natural rate is governed by the rate at which jobs are simultaneously generated and destroyed, the rate of turnover in individual jobs, and how quickly jobless workers are matched with vacant positions (Daly et al. in 2011).

Furuoka (2007) conducted a study in Malaysia where it was examined that during decision making about macroeconomic policies, the Phillips curve has played a significant role. This study found the existence of a long-run tradeoff between inflation and unemployment rate. 
Lagged changes in the unemployment rate affected the change in inflation rate (Lavi and Sussman, 2007). The Conventional Phillips curve represents inflation and unemployment inverse relationship. Many Economists estimated the Phillips curve for developed, middle income countries and as well as for developing countries. Most of them relate the relationship of unemployment to price inflation rather than wage inflation. As they think that the wages paid by the company are closely connected with the price the company charge. Based on the discussion of previous studies and literature, the Natural Rate of Unemployment and the expectations Augmented Philips Curve for Chinese economy can be discovered.

\section{Data \& Methodology}

The methodology used in this study is both empirical and experimental. The data for this study was collected from World Bank website. The data analyzed ranged from 1987 to 2020. Inflation is taken as consumer annual price percentage and unemployment is taken as a percentage of the total labour force.

The Expectations Augmented Phillips Curve that hypothesized that if real inflation rises, expected inflation will also increases, and it will move the Phillips Curve upwards to give the same increase in expected real wage at each employment level. For Expectations Augmented Phillips Curve, we suppose $\pi_{t}$ presents inflation rate at time $t$, which defines the change in price level as a percentage we uses Consumer Price Index (CPI), $U N_{t}$ presents unemployment rate at time $t$, so the Expectations Augmented Phillips Curve can be written as:

$$
\pi_{t}-\pi_{t}^{e}=\beta_{2}\left(U N_{t}-U^{n}\right)+U_{t} \quad \ldots
$$

Where,

$$
\begin{aligned}
\pi_{t} & =\text { Actual Inflation rate at time } t \\
\pi_{t}^{e} & =\text { Expected Inflation rate at time } t, \text { the expectation being formed in year }(t-1) . \\
U N_{t} & =\text { Actual Unemployment rate prevailing at time } t . \\
\mathrm{U}^{\mathrm{n}} & =\text { Natural rate of unemployment at time } \mathrm{t} . \\
\mathrm{U}_{\mathrm{t}} & =\text { Stochastic error term. }
\end{aligned}
$$

As, $\pi_{t}^{e}$ is not directly observable, but it presents a starting point for the assumption that $\pi_{t}^{e}=\pi_{t-1}$ means this year's inflation is predicted to be similar to that of the previous year $(t-1)$. So, equation no I can be written as the regression model in standard form as follows:

$$
\pi_{t}-\pi_{t-1}=\beta_{2} U N_{t}-\beta_{2} U^{n}+U_{t} \quad \cdots
$$

Suppose, $\beta_{1}=-\beta_{2} U^{n}$, so equation (ii) can be written as:

Or

$$
\pi_{t}-\pi_{t-1}=\beta_{1}+\beta_{2} U N_{t}+U_{t} \quad \cdots
$$

$$
\Delta \pi_{t}=\beta_{1}+\beta_{2} U N_{t}+U_{t} \quad \cdots
$$

The Expectations Augmented Phillips Curve argues that changes in inflation rates over two time periods are linearly connected to the present unemployment rate. Now, in order to calculate the Natural Rate of Unemployment, we utilize the following formula: 
Review of Economics and Development Studies, Vol. 7 (4) 2021, 525 - 531

$$
U^{n}=\frac{\text { Expected } \beta_{1}}{\text { Expected }-\beta_{2}} \quad \cdots
$$

Economists estimate that the natural rate of unemployment is between $4 \%$ and $5 \%$. In the figure, $\mathrm{U}^{*}$ is the natural rate of unemployment, also known as the NAIRU (Non-Accelerating Inflation Rate of Unemployment), is defined as "a rate of unemployment in which inflation is neither dropping nor accelerating." If Authorities reduces unemployment below the rate of natural unemployment rate $\mathrm{say}_{1}$, inflation will rise from A to B point on the PC 1 Phillips curve. Now, if a gain in the money pay surpasses the growth in output per person, it will show its natural level on PC2 at point $\mathrm{C}$, which is based on greater predicted inflation. Now, if the government reduces unemployment to U1, the inflation rate will accelerate to point $\mathrm{D}$, but a higher rate of money wages will move the natural rate of unemployment to point $\mathrm{E}$ on $\mathrm{PC}_{3}$, which is based on a higher projected inflation rate. To reduce inflation, the authorities must temporarily raise unemployment above the natural rate point $\mathrm{E}$ to $\mathrm{F}$ on PC3.

Figure 1 presents the Expectations Augmented Phillips Curve

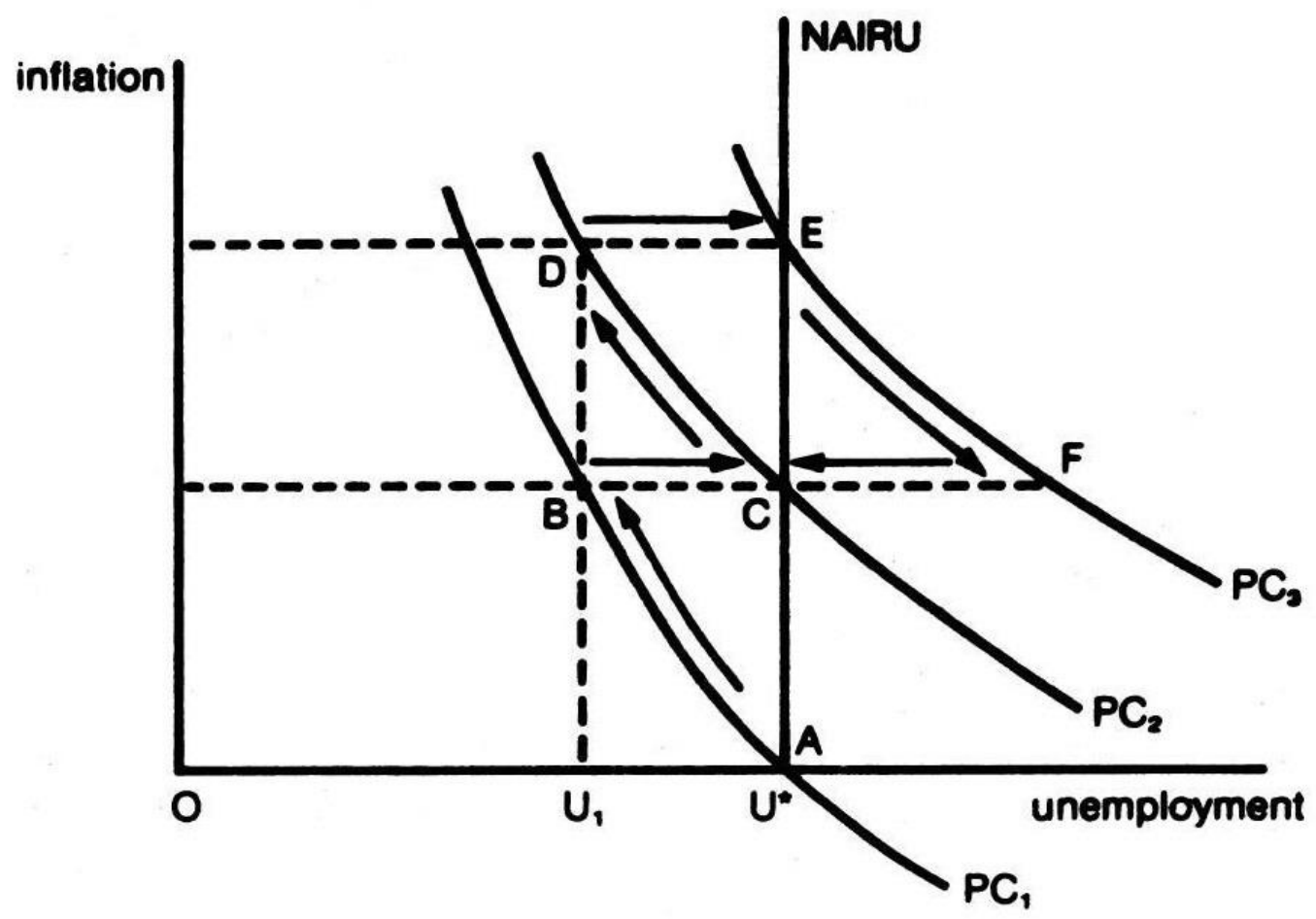

As the money wage rate declines, individuals return to work, and unemployment falls to point C at the Natural level of unemployment, this will lower public expectations about the predicted inflation rate.

\section{Results and Discussion}

Table 1 presents descriptive statistics on inflation and unemployment rate for China from 1987 to 2020. Inflation is taken as consumer annual price percentage and unemployment is taken as a percentage of the total labour force. 
Review of Economics and Development Studies, Vol. 7 (4) 2021, 525 - 531

Table 1: Descriptive Statistics

\begin{tabular}{|l|l|l|l|l|l|}
\hline Variables & Mean & Std. Dev. & Minimum & Maximum & Observations \\
\hline INF & 4.9674 & 6.2599 & -1.4 & 24.26 & 34 \\
\hline UNEM & 3.5794 & 0.8585 & 2 & 5.15 & 34 \\
\hline
\end{tabular}

1. Source: World Bank Development Indicators.

2. Notes: INF = Inflation, Consumer Prices (Annual \%),

UNEM = Unemployment, Total (\% of Total Labor Force).

Inflation with a mean value of 4.9674 having a Standard Deviation of 6.2599 and Unemployment mean value is 3.5794 with 0.8585 is the standard deviation. The correlation for Inflation and Unemployment rate is -0.5325 which show the negative relationship main reason for Phillips the curve is -0.5325 which show the negative relationship main reason for Phillips Curve. Figure 1 presents the original Phillips curve drawn from real-time data and clearly showing that inflation and unemployment have a negative relationship.

\section{Figure 2: Phillips Curve of China}

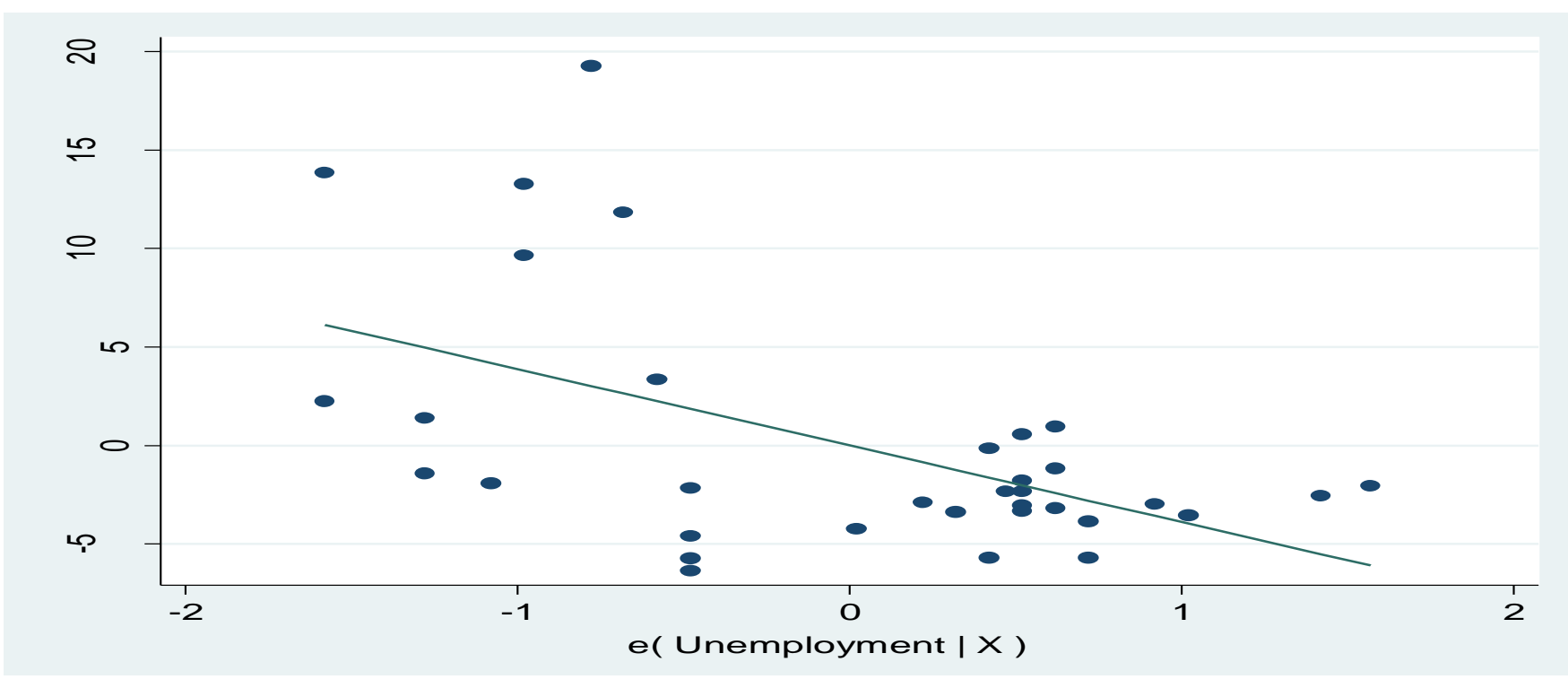

As expected, there is a negative relationship between inflation and unemployment rate; a low unemployment rate would lead to increases in inflation, indicating price acceleration.

The research model presents the following results as under:

$$
\begin{gathered}
\pi_{t}-\pi_{t-1}=18.8652-3.8827 U N_{t} \quad \ldots \quad(6) \\
\beta_{1}=18.8652^{* * *}, \beta_{2}=-3.8827^{* * *}, \quad R^{2}=0.284 \\
t=-3.56, \quad=4.70
\end{gathered}
$$

Model equation 6 illustrates that if the unemployment rate falls by 1 per cent, on average inflation rate goes up by about -3.8827 per cent. Equations VI also shows, if unemployment will go down to zero (o), the inflation will be 18.8652 for the next year. Both coefficients $\beta_{1} \& \beta_{2}$ are significant at 1 per cent level of significance. 
The natural rate of unemployment is the rate of unemployment required to maintain a constant rate of inflation. As a result, the natural rate of unemployment is also known as the non-accelerating unemployment rate (NAIRU).

Here, the natural rate of unemployment can be calculated as,

$$
\boldsymbol{U}^{\boldsymbol{n}}=\frac{\text { Expected } \beta_{1}}{\text { Expected }-\beta_{2}}=\frac{18.8652}{-(-3.8827)}=4.86 \quad \ldots
$$

As a result, China's natural unemployment rate is at 4.86 per cent. According to economists, the natural rate of unemployment is between 4 and $5 \%$, and China's natural rate of unemployment is exactly what economists predict. According to the OECD economic outlook database in 2009 based on data from 1970 to 2008, the natural rate of unemployment in some European countries was 6 per cent in Denmark, 6 per cent in Germany, 7.5 per cent in Ireland, 5.6 per cent in the Netherlands, 3.9 per cent in Sweden, and 6.7 per cent in the United Kingdom.

\section{Conclusion}

The history of the Phillips curve is strongly linked to the discovery of the Natural Rate of Unemployment. Changes in labour market conditions over time are the only way to adjust the natural rate. Labour market, cross-country differences policies also imply a cross country natural rate of unemployment differences. Phillips curve changes over time and is different for different economies. With time, the conventional Phillips Curve shows contradictory findings. Economists in recent years argued the "broken down" nature of the Phillips Curve (Summers, 2017). Even Phillips curve slope in recent decades has become flatter.

Using data from 1980 to 2020, the current research paper explores the Expectations Augmented Phillips Curve and the natural rate of unemployment in China. The first result is that the relationship between inflation rate and unemployment is negatively significant (it proves the existence of the classical Phillips Curve around 1960) in China, and the second result is that the Expectations Augmented Phillips Curve, which is a reformulation of the Phillips Curve that allows for the effects of price expectations on money wages increases, shows that if the unemployment rate falls by $1 \%$, the average inflation rate rises by about -3.8827 percent. If unemployment will go down to zero (o), the inflation will be 18.8652 for the next year, Second: the study reveals the natural rate of unemployment for China is 4.86 (may be compared to the natural rate of unemployment suggested by economists of 4 to $5 \%$ ), which will be useful for policymakers in sustaining stable inflation circumstances in China.

\section{References}

Ashiya, N. (2017). The Modified Phillips Curve as a possible Answer to Japanese Deflation. Advances in Economics and Business, 5(10).

Brauer, D. (2007). The Natural Rate of Unemployment, CBO Working Paper, 2007-08.

Daly, M., Hobijn, B., \& Valletta, R. (2011). The Recent Evolution of Natural Rate of Unemployment. Federal Reserve Bank of San Francisco, Working Paper, 2011-12.

Franz, W. (2005). Will the (German) NAIRU Please Stand Up?, German Economic Review, 6(2). Humphrey, C. (1985). Barter and Economic Disintegration, Man New Series, 20(1), 48-72.

Karanassou, M., \& Sala, H. (2010). Phillips Curves and Unemployment Dynamics: A Critique and a Holistic Perspective, Journal of Economic Survey, 24(1), 1-51. 
Furuoka, F. (2007). Does the "Phillips curve" really exist? New empirical evidence from Malaysia. Economics Bulletin, 5(16), 1-14.

Lavi, Y., \& Sussman, N. (2007). The Phillips Curve in Israel. Israel Economic Review, 5(1).

Phillips, A.W. (1958). The Relation between Unemployment and the Rate of Change of Money Wage Rates in the United Kingdom, Economica, 25(100), 283-299.

Mitra, S. (2012). A Review of Services Quality Research in India, IMS Management Journal, the Journal of IMS Koltata, 4, 54-66.

Nistanene, W. A. (2002). On the Death of the Phillips Curve, Cato Journal, 22(2), 193-198.

OECD. (2009). Economic Outlook Database.

Summers, L. (2017). America Needs its Unions More Than Ever, Financial Times, 3 September.

Taiwoo, M. A., Ayodeji, A., \& Bako, Y. A. (2013). Impact of Small and Medium Enterprises on Economic Growth and Development, American Journal of Business and Management, 1(1), 18-22. 